\title{
COREOPSIS TINCTORIA NUTT PROTECT HUMAN LIVER CELL FROM OXIDATIVE DAMAGE AND EXHIBIT ANTIOXIDANT CAPABILITY
}

\author{
Xinmei Chen ${ }^{1}$, Chao $\mathrm{Cen}^{2}$, Yali $\mathrm{Li}^{3}$, Muhuyati Wulasihan ${ }^{3}$ \\ ${ }^{1}$ The Department of Pharmacy, Shandong University of Traditional Chinese Medicine, Jinan \\ Shandong, China, 250014 \\ ${ }^{2}$ The First Affiliated Hospital, Zhejiang University, Hangzhou, China, 310003 \\ ${ }^{3}$ The Department of Internal Medicine, the First Affiliated Hospital of Xinjiang Medical \\ University Urumqi, Xinjiang, China, 830000
}

Co-corresponding Author: Yali Li, E-mail: lylemail@sina.cn. Muhuyati Wulasihan, E-mail: muhuyati@163.com, The Department of Internal Medicine, The First Affiliated Hospital of Xinjiang Medical University Urumqi, Xinjiang, China, 830000;

\begin{abstract}
Background: The aim of the present study was to evaluate the antioxidant effect and the mechanism of total extract and two isolated compounds derived from Coreopsis tinctoria Nutt. on human hepatocyte LO2 injured by hydrogen peroxide in vitro.
\end{abstract}

Methods: The chemical compounds of Coreopsis tinctoria Nutt. were isolated and identified. The cell model with oxidative damage was set up by adding $\mathrm{H}_{2} \mathrm{O}_{2}$ in normal liver cell LO2. LO2 cells were pre-incubated with Coreopsis tinctoria Nutt compounds to test cell viability, nitric oxide release, caspase activity and apoptosis. The protective effect against oxidative damage were measured and the mechanism was analyzed by DPPH radical scavenging activity, ABTS $+\bullet$ radical-scavenging assay and reducing power $(\mathrm{Fe} 3+)$ assay

Results: The study showed that incubation with Coreopsis tinctoria Nutt caused significant increase in the viability of LO2 cell, decrease of nitric oxide release, caspase activity and cell apoptosis in LO2 cell injured by hydrogen peroxide. The Coreopsis tinctoria Nutt and its two compounds showed antioxidant abilities.

Conclusions: Coreopsis tinctoria Nutt protect normal human liver cells against oxidative induced DNA damage and apoptosis by reducing nitric oxide release. One mechanism of protective effect may be radical-scavenging which is via donating hydrogen atom $(\mathrm{H} \cdot)$, donating electron $(\mathrm{e})$.

Keywords: oxidative damage; Coreopsis tinctoria Nutt. antioxidant protection; liver cell LO2 


\section{INTRODUCTION}

Coreopsis tinctoria Nutt has been used to prevent cardiovascular disease (Sun YH, et al). Dias T, et al report it is also effect to control high glucose (Dias T, et al). But the medical function and mechanism of Coreopsis tinctoria Nutt have not been fully explored. This study investigates the potential antioxidant benefits of Coreopsis tinctoria Nutt. on human liver cells and investigate the possible molecular mechanism.

\section{METHODS}

\subsection{Chemicals and plant compounds derived from plant extract}

Flowers of Coreopsis tinctoria Nutt. were planted in Xinjiang (Figure 1A). Healthy flower were separated, shade dried, and pulverized mechanically (Figure 2). The crude extracts were qualitatively identified for separate chemical compounds to provide the chemical basis for further analysis (Figure 3). The isolation progress has been optimized to get the total flavonoid from Coreopsis tinctoria Nutt by ethanol extraction, column chromatography and crystallization by referring the methodology of other herb extraction (Dias $\mathrm{T}$, et al). Trolox is a standard antioxidant purchased from Sigma, U.S.A. Total nitric oxide assay kit was purchased from Beyotime, Shanghai, China.

\subsection{Cell culture}

Human normal hepatocellular cell line LO2 was purchased from Chinese Academy of Science (Shanghai, China). Cells were grown in RPMI 1640 medium supplemented with $10 \%$ FBS, penicillin
(100 unit/mL), streptomycin $(0.1 \mathrm{mg} / \mathrm{mL})$, $1 \mu \mathrm{g} / \mathrm{ml}$ glucose and $0.25 \mathrm{U} / \mathrm{ml}$ insulin. The cells were incubated at $37{ }^{\circ} \mathrm{C}$ in a humidified incubator under an atmosphere of $5 \% \mathrm{CO} 2$.

\subsection{Oxidative damage induced by $\mathrm{H}_{2} \mathrm{O}_{2}$}

LO2 cell was cultured in 96-well plates at a density of $2 \times 105$ cells $/ \mathrm{mL}$. The cells were treated with $100 \mu \mathrm{mol} / \mathrm{L} \mathrm{H}_{2} \mathrm{O}_{2}$ for $24 \mathrm{~h}$ incubation except control group.

\subsection{Measurement of cell viability}

The cells were divided into control group, $\mathrm{H}_{2} \mathrm{O}_{2}$ group and high, medium and low concentrations $(20,50$, and $100 \mu \mathrm{mol} / \mathrm{L})$. The viability of LO2 cell was measured by a colorimetric MTT assay. After the cells were treated by $\mathrm{H}_{2} \mathrm{O}_{2}$ $(100 \mu \mathrm{mol} / \mathrm{L})$ and different concentrations of Coreopsis tinctoria Nutt and its compounds respectively for $24 \mathrm{~h} .50 \mu \mathrm{L}$ MTT solution $(1 \mathrm{mg} / \mathrm{mL})$ was added to each well and then incubated at $37^{\circ} \mathrm{C}$ for $4 \mathrm{~h}$. After medium was removed, the crystal dye was dissolved in $100 \mu \mathrm{L}$ DMSO to read the optical density (OD) on ELISA micro-plate reader (BIO-RAD, USA) at $490 \mathrm{~nm}$.

\subsection{Measurement of nitric oxide release}

When cells were in log phage, $100 \mu \mathrm{mol} / \mathrm{L} \mathrm{H}_{2} \mathrm{O}_{2}$ or $20,50,100 \mu \mathrm{mol} / \mathrm{L}$ Coreopsis tinctoria Nutt and its compounds were added to LO2 cells. After being incubated for $24 \mathrm{~h}$, cells were collected and washed twice with PBS. The cells were stained for apoptosis morphology observation. The supernatant was collected to measure nitric oxide release by using 
nitric oxide assay kit.

\subsection{Protective effect against DNA damage}

Coreopsis tinctoria Nutt extracts were dissolved in methanol $(5 \mathrm{mg} / \mathrm{mL})$. Different concentration $(0-100 \mu \mathrm{L})$ of mixture were then put into mini tubes. After evaporating, $400 \mu \mathrm{L}$ of phosphate buffer $(0.2 \mathrm{~mol} / \mathrm{L}, \mathrm{pH}$ 7.4) was added to the tube. $50 \mu \mathrm{L}$ DNA sodium $(10.0 \mathrm{mg} / \mathrm{mL}) .50 \mu \mathrm{L} \mathrm{H} 2 \mathrm{O} 2(50$ $\mathrm{mmol} / \mathrm{L}), 50 \mu \mathrm{L} \mathrm{FeCl} 3(3.2 \mathrm{mmol} / \mathrm{L})$ and $50 \mu \mathrm{L} \mathrm{Na}{ }_{2}$ EDTA $(1 \mathrm{mmol} / \mathrm{L})$ were added. Then $50 \mu \mathrm{L}$ of ascorbic acid $(18 \mathrm{mmol} / \mathrm{L})$ were added to initiate reaction in a water bath at $55{ }^{\circ} \mathrm{C}$ for $20 \mathrm{~min}, 250 \mu \mathrm{L}$ of trichloroacetic acid $(10 \mathrm{~g} / 100 \mathrm{~mL}$ water) was then added to terminate reaction. The color was then developed by addition of $150 \mu \mathrm{L}$ of TBA (2-thiobarbituric acid) $(0.4 \mathrm{~mol} / \mathrm{L}$, in $1.25 \% \mathrm{NaOH}$ aqueous solution) at $105{ }^{\circ} \mathrm{C}$ for $15 \mathrm{~min}$. The tubes were cooled and absorbance was measured at $530 \mathrm{~nm}$ against the blank buffer as control. The percent of protection against DNA damage is expressed as follows: Protective effect \% $=(1-\mathrm{A} / \mathrm{A} 0) \times 100$

\subsection{DPPH radical scavenging activity}

Free radical scavenging activity of the extracts was carried based on the scavenging activity of stable DPPH. Coreopsis tinctoria Nutt extracts $(5 \mathrm{mg} / \mathrm{mL}$ ) were added to each tube and then were incubated at room temperature in dark room for $30 \mathrm{~min}$. The scavenging activity on the DPPH radical was determined by measuring the absorbance at $519 \mathrm{~nm}$ with a spectrophotometer (Unico 2100, Shanghai, China). Radical scavenging activity was calculated using the formula: The DPPH• inhibition percentage was calculated as: Inhibition $\%=(1-\mathrm{A} / \mathrm{A} 0) \times 100 \%$, where $\mathrm{A}$ is the absorbance with samples, while A0 is the absorbance without samples.

\subsection{ABTS $+\bullet$ radical-scavenging assay}

The ABTS+・ -scavenging activity was measured as described. The ABTS+• was generated by $0.35 \mathrm{~mL}$ ABTS diammonium salt $(7.4 \mathrm{mmol} / \mathrm{L})$ mixed with potassium $0.35 \mathrm{~mL}$ persuylfate $(2.6 \mathrm{mmol} / \mathrm{L})$. The solution was kept in the dark room for $12 \mathrm{~h}$ for radical generation, and then diluted with 1:50 ethanol. To determine the radical-scavenging activity, $1.2 \mathrm{~mL}$ ABTS + - reagent was diluted by $0.3 \mathrm{~mL}$ of Coreopsis tinctoria Nutt extracts (0.08-0.4 $\mathrm{mg} / \mathrm{mL}$ ). After incubation for $5 \mathrm{~min}$, the absorbance at $734 \mathrm{~nm}$ was read on a spectrophotometer (Unico 2100, Shanghai, China). The percentage inhibition was calculated as: Inhibition $\%=(1-\mathrm{A} / \mathrm{A} 0)$ $\times 100 \%$ in which, A0 is the absorbance of the mixture without sample, $A$ is the absorbance of the mixture with sample

\subsection{Reducing power $\left(\mathrm{Fe}^{3+}\right)$ assay}

Ferric $\left(\mathrm{Fe}^{3+}\right)$ reducing power was determined by mixing Coreopsis tinctoria Nutt extracts with $\mathrm{Na}_{2} \mathrm{HPO} / \mathrm{KH} 2 \mathrm{PO} 4$ buffer $(0.2 \mathrm{~mol} / \mathrm{L}, \mathrm{pH}$ 6. 6) and $250 \mu \mathrm{L}$ $\mathrm{K}_{3} \mathrm{Fe}(\mathrm{CN}) 6$ aqueous solution $(1 \mathrm{~g} / 100 \mathrm{~mL})$ at $50{ }^{\circ} \mathrm{C}$ for $20 \mathrm{~min}$. $250 \mu \mathrm{L}$ of trichloroacetic acid $(10 \mathrm{~g} / 100 \mathrm{~mL}) \mathrm{t}$ was added to the mixture and centrifuged at $3500 \mathrm{r} / \mathrm{min}$ for $10 \mathrm{~min}$. The $400 \mu \mathrm{L}$ supernatant was then aliquoted into $400 \mu \mathrm{L}$ $\mathrm{FeCl}_{3}(0.1 \mathrm{~g} / 100 \mathrm{~mL}$ in distilled water $)$ and incubated for $90 \mathrm{~s}$. The absorbance was measure at $700 \mathrm{~nm}$ (Unico 2100, Shanghai, China). The relative reducing ability of the sample was calculated by using the formula: Relative reducing effect $\%=$ (A-Amin)/ (Amax-Amin) $\times 100 \%$ in which, 
Amax is the maximum absorbance and Amin is the minimum absorbance in the test. $\mathrm{A}$ is the absorbance of sample.

\subsection{Statistical analysis}

Data are given as the mean $\pm \mathrm{SD}$ of three measurements. The IC50 values were calculated by linear regression analysis. Significant differences were performed using one-way ANOVA ( $\mathrm{p}<0.05$ ) with SPSS software (v.12, SPSS, USA)

\section{RESULTS}

\subsection{Plant compounds derived from plant} extract

Flowers of Coreopsis tinctoria Nutt. were planted in Dabancheng, Xinjiang (Figure 1A). Healthy flower were separated, shade dried, and pulverized mechanically. The crude extracts were qualitatively examined for chemical compounds to provide the chemical basis for development and utilization of this plant. The extraction progress has been optimized to get the total flavonoid from Coreopsis tinctoria Nutt by ethanol extraction, column chromatography and crystallization. The separate compounds from Coreopsis tinctoria Nutt. have been isolated and identified. The compounds include the total flavonoid (XJE) and two major compounds (XJ01,XJ02 with the highest production were applied in the antioxidative study (Figure 1B). Coreopsis tinctoria Nutt. were extracted with water under reflux. The extracted liquids were pooled and concentrated under vacuum. Then ethanol was added to the concentrate and filtered. The supernatant was concentrated under vacuum to get the crude extract (Figure 2). Quantitative analysis was carried out by HPLC on Shimadzu Prominence LC-20A liquid chromatographic system (Shimadzu instruments company, Japan) comprising binary pumps, a PDA detector and LC solution software (Figure3) with the operation condition reported ( Eugene NO et al)

\subsection{Protection Effect on $\mathrm{H}_{2} \mathrm{O}_{2}$ injured cell viability}

$\mathrm{H}_{2} \mathrm{O}_{2}$ remarkably decreased the viability of cell, while XJE, XJ01 and XJ02 $(20,50$, and $100 \mu \mathrm{M})$ relived the cell damage induced by $\mathrm{H}_{2} \mathrm{O}_{2}$ in a dose-dependent manner after $24 \mathrm{~h}$ treatment (Figure 4A). The result suggests that XJE, $\mathrm{XJ} 01$ and $\mathrm{XJ} 02$ protects $\mathrm{LO} 2$ cell from oxidative damage.

\subsection{Effects of Coreopsis tinctoria Nutt on inhibiting nitric oxide release in $\mathrm{H} 2 \mathrm{O} 2$ injured LO2 cell}

Incubation of $\mathrm{LO} 2$ cell with $\mathrm{H} 2 \mathrm{O} 2$ for $24 \mathrm{~h}$ caused a significant increase in nitric oxide release in the medium, while incubation of the cell with Coreopsis tinctoria Nutt (20, 50, and 100uM) significantly attenuated the increased nitric oxide level (Figure 4B).

\subsection{Measurement of Antioxidant Activity}

The antioxidant activity was analyzed using in vitro methods such as DPPH radical scavenging, ferric reducing antioxidant power activity, ABTS radical cation scavenging activity (Figure5).

Hydroxyl radical $(\cdot \mathrm{OH})$ is extreme reactive and easily damage DNA to produce malondialdehyde (MDA) and various oxidative lesions. MDA combines 2-thiobarbituric acid (TBA) to yield thiobarbituric acid reactive substances 
(TBARS) which present a maximum absorbance at $530 \mathrm{~nm}$. The absorbance of A530nm can reflect the amount of MDA and DNA damage. So in the study the decrease of $A 530 \mathrm{~nm}$ value indicates a protective effect against DNA damage. As seen in Figure 5, Coreopsis tinctoria Nutt extracts showed a protective effect against DNA damage in a dose dependent manner and the IC50 values were significantly higher than positive control-trolox, a well known antioxidant agent.

The DPPH method is used for examining the general antioxidant activity because DPPH itself is a stable nitrogen-centered free radical. The color changes was caused by the formation of diphenyl picryl hydrazine, a stable diamagnetic molecule. Our results show that the DPPH radical scavenging activity of XJE, XJ01 and XJ02 was increased in a dose-dependent manner (Figure 5).

The Fe3+reducing assay provides fast reproducible results, measures the ability of an antioxidant to reduce $\mathrm{Fe} 3+$ to $\mathrm{Fe} 2+$ ), which is blue in color and can be detected. Fe3+reducing assay showed a dose-dependent manner.

Figure 5 also shows ABTS radical scavenging activity of XJE, XJ01 and XJ02 was increased in a dose-dependent manner. Figure 5 suggest that XJE, XJ01 and XJ02 exhibited appreciable antioxidant ability at all three test concentrations. The most substantial antioxidant capacity was observed at the highest concentration (100 Um).

\section{DISCUSSION}

People live under many degradative stresses, such as ROS and free radicals. These reactive species extensively cause the oxidative damage to the bimolecular nucleic acids, proteins, lipid damage and as a result oxidative stress related diseases such as cancer, ageing, heart failure, ulcer occur (Sanchez-Moreno C, et al).Many natural herbs are good antioxidants and possible protective agents against oxidative damage of the human body. In this study, the antioxidant activity of Coreopsis tinctoria Nutt extracts and its two compounds were investigated.

Photochemical studies suggested that total phenolics and total flavonoid can be responsible for the antioxidant ability in plants (Demo A); We then determined the total phenolics and total flavonoid contents in Coreopsis tinctoria Nutt extracts. The data showed that Coreopsis tinctoria Nutt extracts contained high amounts of total phenolics and flavonoid.

There are two pathways for natural phenolic antioxidant to protect DNA oxidative damage: one is to scavenge the - $\mathrm{OH}$ radicals so that its attack is reduced; the other is to repair the deoxynucleotide radical cations damaged by $\bullet \mathrm{OH}$ radicals. We then tested the repaire function by measuring the DPPH - and ABTS $+\cdot$ radical-scavenging abilities.

The DPPH and ABTS $+\cdot$ radical-scavenging assays showed that Coreopsis tinctoria Nutt extracts can effectively eliminate DPPH • radical (Figure 5) and ABTS+·radical (Figure 5). Because a reductant is not necessarily an antioxidant while an antioxidant is commonly a reductant. We further tested the reducing power of Coreopsis tinctoria Nutt extracts as a significant indicator of its potential antioxidant activity. Figure 5 showed that Coreopsis tinctoria Nutt extracts exhibited reducing power on $\mathrm{Fe} 3+$. It indicate that the protective effect of Coreopsis tinctoria Nutt extracts against DNA oxidative damage was induced by their radical-scavenging 
ability of donating hydrogen atom $\left(\mathrm{H}^{\cdot}\right)$ and electron (e).

\section{CONCLUSION}

Snow mountain herbal medicine Coreopsis tinctoria Nutt can effectively protect against hydroxyl-induced DNA damage. One mechanism of protective effect may be radical-scavenging which is via donating hydrogen atom $(\mathrm{H} \cdot)$, donating electron (e). Its antioxidant ability can be mainly attributed to the chemical structure of flavonoid or total phenolics.

\section{ACKNOWLEDGEMENT}

The research is supported by National Natural Science Foundation of China (81372425, 81460634), Xinjiang Science and Technology Bureau Project (No.2013911131) and Xinjiang Medical University Natural Science Grant (No. 2013ZRZD07) 


\section{REFERENCES}

Demo A, Petrakis Ch, Kefalas P, Boskou D. Nutrient antioxidants in some herbs and mediterranean plant leaves. Food Res Int. 1998;32:351-4.

Dias T, Liu B, Jones P, Houghton PJ, Mota-Filipe H, Paulo A. Cytoprotective effect of Coreopsis tinctoria extracts and flavonoids on tBHP and cytokine-induced cell injury in pancreatic MIN6 cells.J Ethnopharmacol. 2012 Jan 31;139(2):485-92. doi: 10.1016/j.jep.2011.11.038. Epub 2011 Nov 28.

Dias T, Bronze MR, Houghton PJ, Mota-Filipe H, Paulo A. The flavonoid-rich fraction of Coreopsis tinctoria promotes glucose tolerance regain through pancreatic function recovery in streptozotocin-induced glucose-intolerant rats. J Ethnopharmacol. 2010 Nov 11;132(2):483-90. [PubMed: 20813179]

Eugene NO, Jude CI, Catherine CI, Augustine AU. Quantitative high performance liquid chromatographic analysis of simple terpenes, carotenoids, phytosterols and flavonoids in the leaves of Acalypha wilkesiana Muell Arg. Pac J Sci Technol. 2010;11:480-7.

Sanchez-Moreno C, Larrauri JA, Saura-Calixto F. Free radical scavenging capacity and inhibition of lipid oxidation of wines, grape juices and related polyphenolic constituents. Food Res Int. 1999;32:407-12.
Sun YH, Zhao J, Jin HT, Cao Y, Ming T, Zhang LL, Hu MY, Hamlati H, Pang SB, Ma XP.Vasorelaxant effects of the extracts and some flavonoid from the buds of Coreopsis tinctoria. Pharm Biol. 2013 Sep;51(9):1158-64. 
Figure. 1. Coreopsis tinctoria Nutt

The flower of Coreopsis tinctoria Nutt grown in South Xinjiang China (Figure 1A) and the basic chemical structure of its major compounds (Figure 1B).

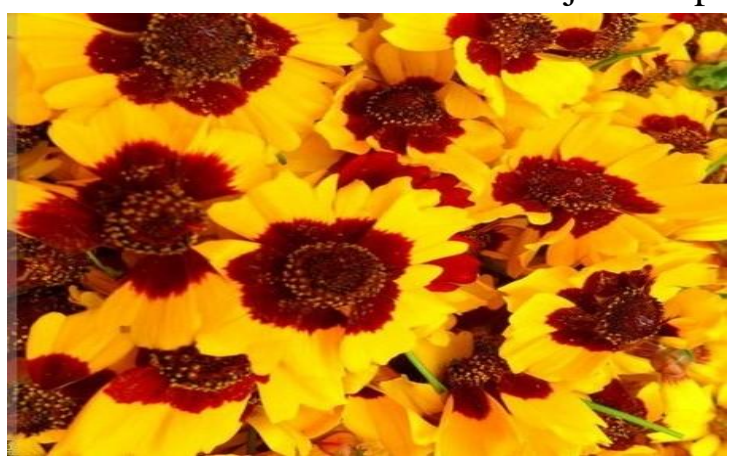<smiles>O=c1cc(-c2ccc(O)cc2)oc2cc(O)cc(O)c12</smiles>

Figure. 2. Coreopsis tinctoria Nutt extraction

The flower of Coreopsis tinctoria Nutt were separated, shade dried, and pulverized mechanically and then processed by ethanol extraction, column chromatography and crystallization. Coreopsis tinctoria Nutt. were extracted with water under reflux. The extracted liquids were pooled and concentrated under vacuum. Then ethanol was added to the concentrate and filtered. The supernatant was concentrated under vacuum to get the crude extract.

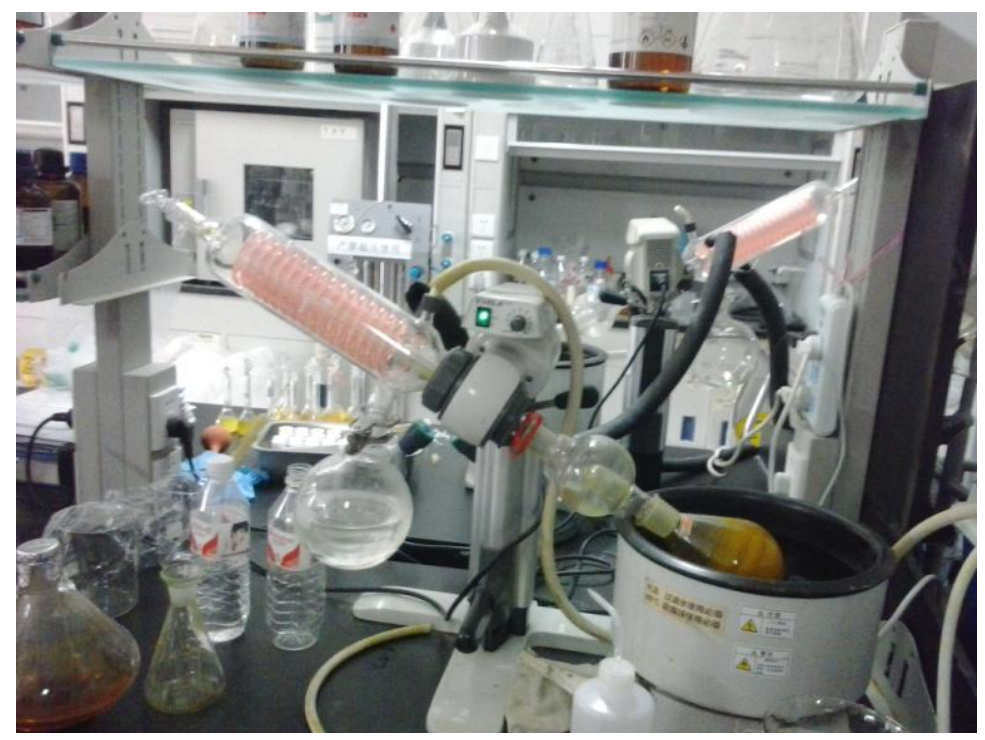

\section{Figure. 3. Coreopsis tinctoria Nutt separation and identification}

The flower of Coreopsis tinctoria Nutt extract was separated and identified by quantitative high performance liquid chromatographic analysis. Quantitative analysis was carried out by HPLC on Shimadzu Prominence LC-20A liquid chromatographic system (Shimadzu instruments company, Japan) comprising binary pumps, a PDA detector and LC solution software. 


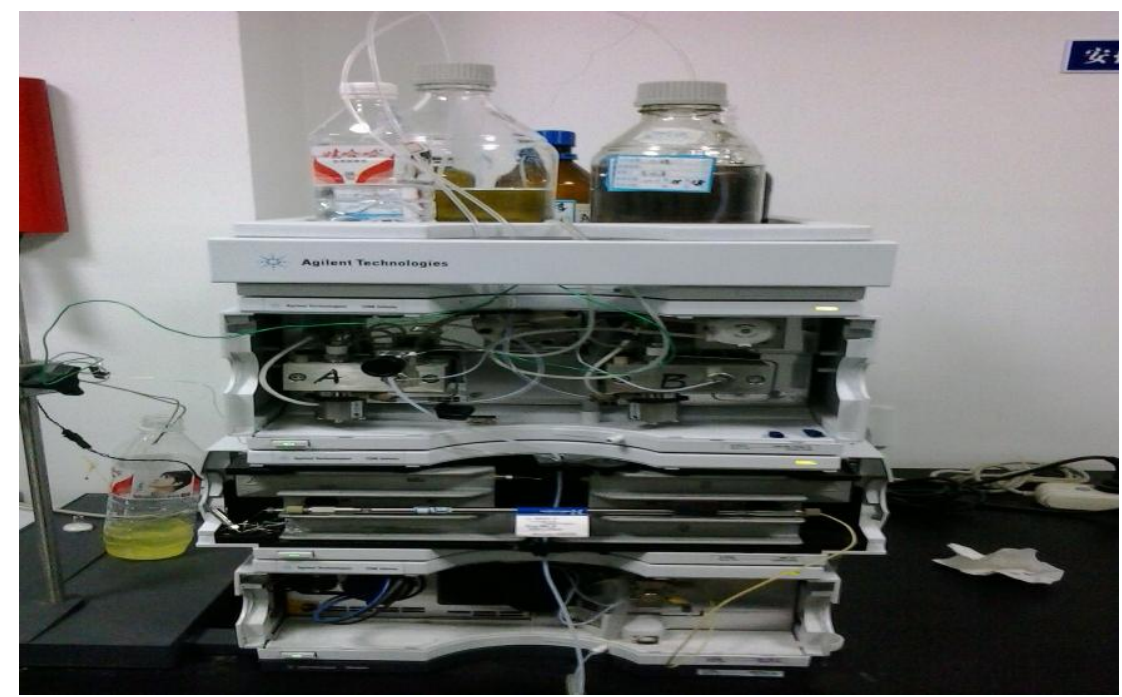

Figure. 4. Effect of Coreopsis tinctoria Nutt. on increasing cell viability in $\mathrm{H}_{2} \mathrm{O}_{2}$ injured LO2 cell by inhibiting NO release in the cells damaged by $\mathrm{H}_{2} \mathrm{O}_{2}$.

Incubation of $\mathrm{LO} 2$ cell with $\mathrm{H}_{2} \mathrm{O}_{2}$ for $24 \mathrm{~h}$ caused a significant increase in NO release in the medium, while the pre-incubation with Coreopsis tinctoria Nutt (20, 50, and 100uM) significantly attenuated the increased NO level (Figure 2B) and recover the cell viability (Figure 2A). Results were shown as mean $\pm \mathrm{SD}(\mathrm{n}=8)$. $* \mathrm{P}<0.05$, compared with control.

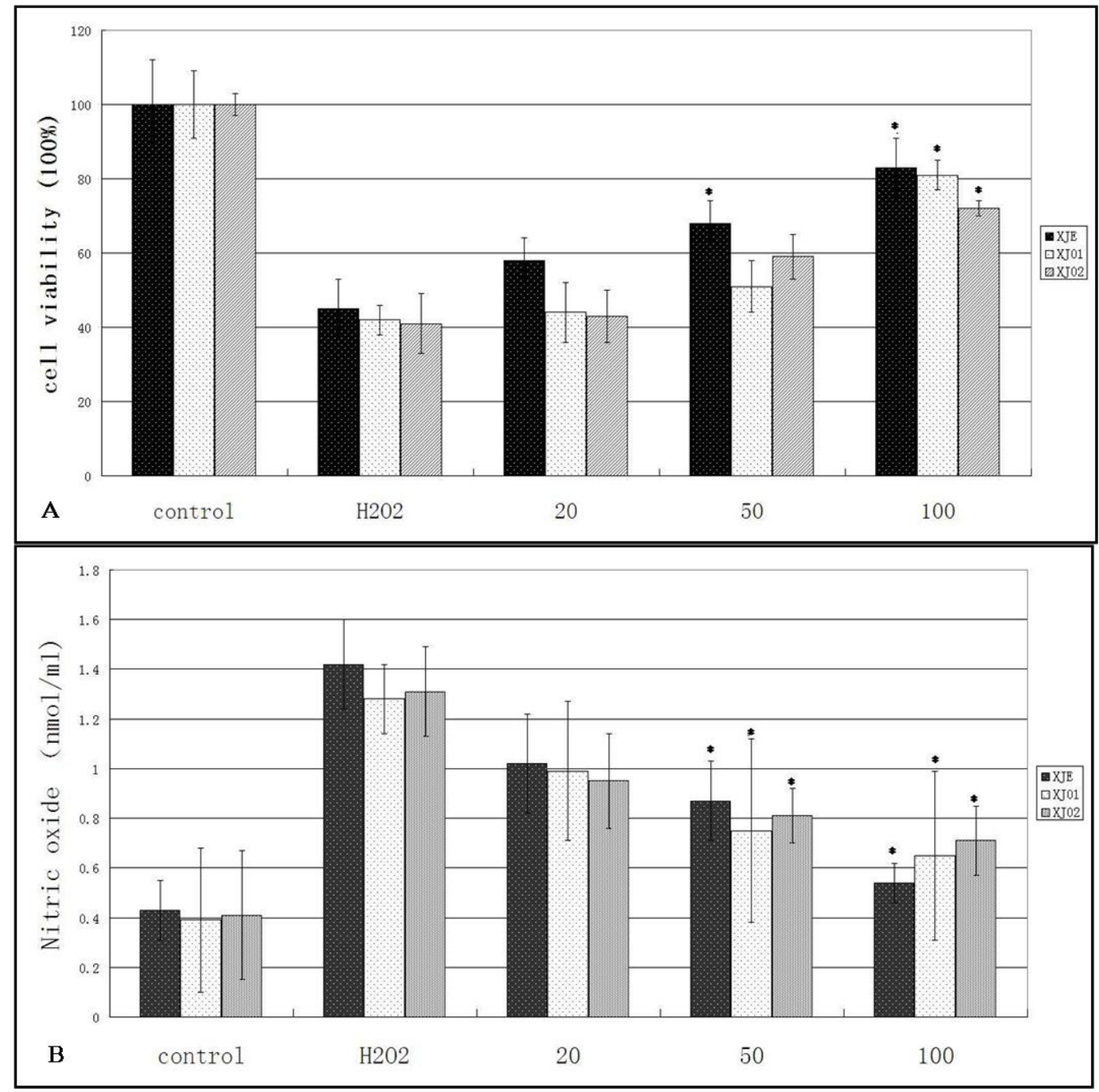


Figure 5 Antioxidant activity of Coreopsis tinctoria Nutt in $\mathrm{H}_{2} \mathrm{O}_{2}$ injured $\mathrm{LO} 2$ cell

The test of antioxidant assays include (A) protective effect on DNA damage; (B) DPPH - scavenging; (C) ABTS+· scavenging (D) $\mathrm{Fe}^{3+}$-reducing; Trolox was used as the positive controls. Each value is expressed as Mean $\pm \mathrm{SD}(\mathrm{n}=3)$. IC50 value was defined as the concentration of $50 \%$ effect percentage and expressed as Mean $\pm \operatorname{SD} \quad(n=3)$.

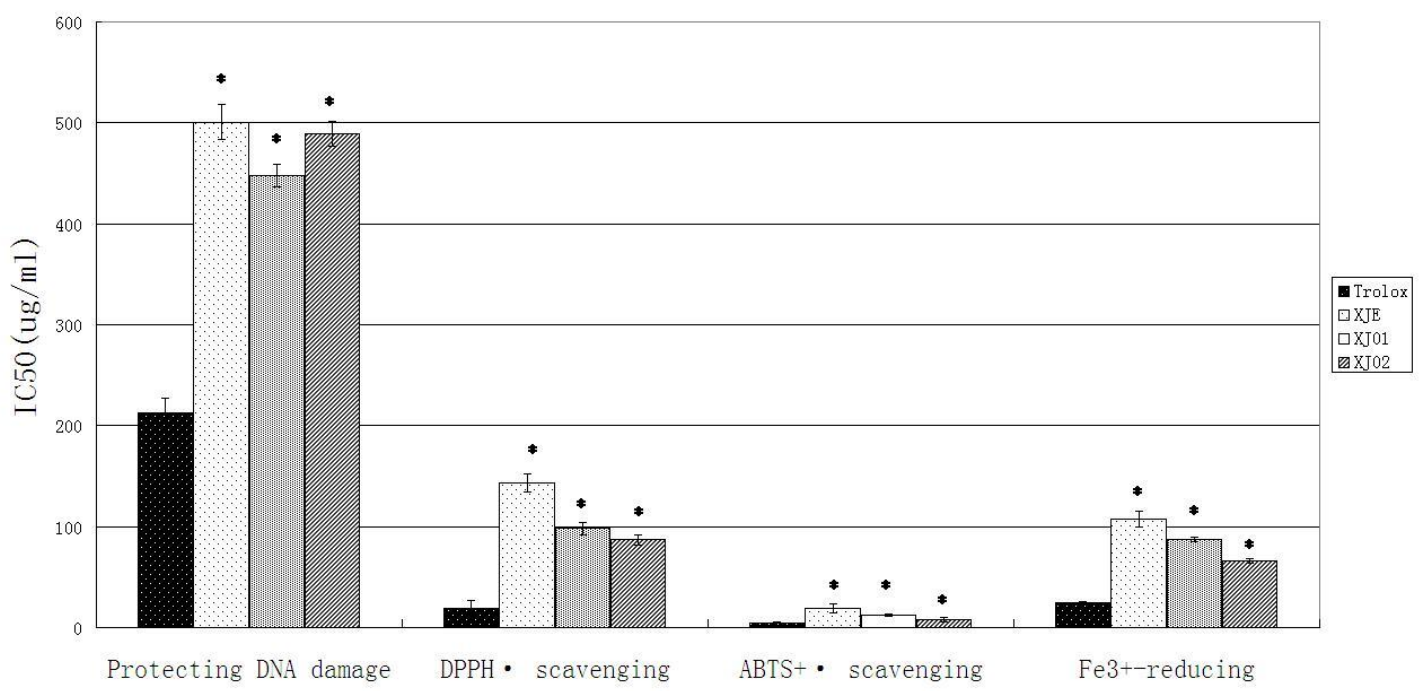

